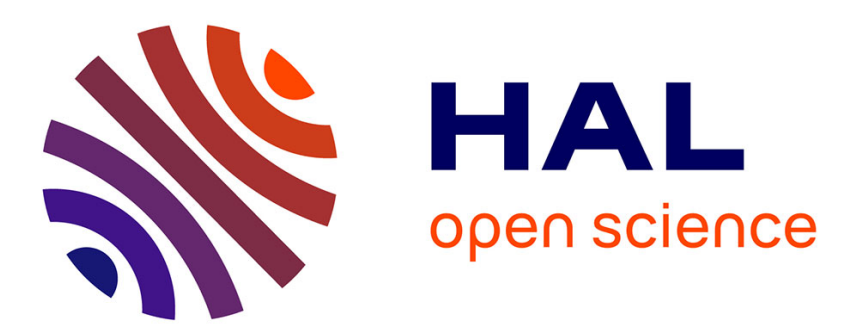

\title{
Credit rationing or overlending? An exploration into financing imperfection
}

Jean Bonnet, Sylvie Cieply, Marcus Dejardin

\section{To cite this version:}

Jean Bonnet, Sylvie Cieply, Marcus Dejardin. Credit rationing or overlending? An exploration into financing imperfection. Applied Economics, 2016, 48 (57), pp.5563-5580. 10.1080/00036846.2016.1181829. halshs-01373017

\section{HAL Id: halshs-01373017 https://shs.hal.science/halshs-01373017}

Submitted on 30 Sep 2016

HAL is a multi-disciplinary open access archive for the deposit and dissemination of scientific research documents, whether they are published or not. The documents may come from teaching and research institutions in France or abroad, or from public or private research centers.
L'archive ouverte pluridisciplinaire HAL, est destinée au dépôt et à la diffusion de documents scientifiques de niveau recherche, publiés ou non, émanant des établissements d'enseignement et de recherche français ou étrangers, des laboratoires publics ou privés. 


\title{
CREDit RATIONING OR OVERLENDING? AN EXPLORATION INTO FINANCING IMPERFECTION
}

\author{
Jean Bonnet *, Sylvie Cieply ${ }^{* *}$ and Marcus Dejardin *** \\ * University of Caen, CREM-CAEN, UMR CNRS 6211, Faculty of Economics and Business Administration, \\ 19, rue Claude Bloch, 14032 Caen, France, jean.bonnet@unicaen.fr \\ ** University of Caen, CREM-CAEN, UMR CNRS 6211, Institut Banque-Assurance, \\ 19 rue Claude Bloch, 14032 Caen, France, sylvie.cieply@unicaen.fr \\ *** Université catholique de Louvain and University of Namur, CERPE, Faculty of Economics, Social Sciences and \\ Business Administration, \\ 8, Rempart de la Vierge, 5000 Namur, Belgium, marcus.dejardin@ unamur.be
}

April 20, 2016

\begin{abstract}
:
Small and new firms are deemed to be unable to obtain sufficient banking loans. This idea finds a strong theoretical support in credit rationing theory, as initiated by Stiglitz and Weiss (1981). However, this is vigorously challenged by De Meza and Webb (1987, 2000) suggesting that firms can benefit from an excess of credit, i.e. overlending. Credit rationing or overlending? The contribution of this empirical article is twofold: to our knowledge, it is the first to make an attempt in measuring the relative importance of these two types of financing imperfection and to explore factors leading to one or the other. We exploit a rich panel dataset on the access to banking credit for new French businesses during the mid-1990s. Our results show that credit rationing was not highly spread among French new firms. The story described by De Meza and Webb (1987) appears to be a much more realistic model. In addition, we identify factors, linked to the starter, the project or the industry, that are closely associated with credit rationing and/or overlending. Most factors enter into a consistent relation: when they are positively (negatively) associated with credit rationing, they are negatively (positively) associated with overlending.
\end{abstract}

\section{Keywords:}

Credit rationing, Overlending, Imperfect information, Asymmetric information, New business.

\section{JEL Classification:}

M13, G21, D82

Acknowledgments: Authors would like to thank the journal's anonymous referees, and Jacques Melitz, Alex Coad, David Storey, Hélène Laurent, Paulo Rodrigues and Philippe Lemay-Boucher for suggestions or comments on earlier versions of this article. 


\section{1- Introduction}

Banks exist because they screen and monitor borrowers more efficiently than other investors can (Goodhart, 1989, Bhattacharya and Thakor, 1993, Allen and Santomero, 1998, Fama, 1985). They are specialized in gathering private information and treating it (Freixas and Rochet, 1999). Managing money and deposit accounts, banks own highly strategic information on firms' receipts and expenditures as well as the way that firms develop (Ruhle, 1997, Diamond and Rajan, 2001). Despite this glut of information, relationships between bankers and firms are not perfect and bankers can make errors in granting (or not granting) credit. Banks indeed suffer from informational asymmetries (Freixas and Rochet, 1999) such that evolution of prices (interest rates) cannot clear the credit market. Finally, a non-Walrasian equilibrium arises with a fringe of unsatisfied agents.

According to the seminal theoretical Stiglitz and Weiss (1981) paper, unsatisfied agents are borrowers. Asymmetric information leads to credit rationing albeit the high quality of the borrower, as lenders cannot distinguish between high quality and low quality borrowers. However, this dominate view is not without criticism. In particular, De Meza and Webb (1987) vigorously contest this result. They show that asymmetric information in credit markets can lead to the inverse result, which is an excess of credit, i.e. overlending albeit the low quality of the borrower.

Our objective within this empirical paper is twofold. First, we make an attempt in measuring the relative importance of these two types of financing imperfection, if any, that represent credit rationing and overlending. We collect evidence that identifies the most prevalent errors made by bankers on the credit market. Although the empirical literature is abundant with regard to credit rationing, we cannot identify any work assessing the existence of overlending and/or its coexistence with credit rationing. In this article, we focus on the market of credit to new firms. Indeed, new firms are opaque, producing little credible information and, inherently, cannot exhibit any track record to bankers. They are also the subject of specific attention from policymakers because they are supposed to suffer structurally from financial constraints. Second, we contribute to identify the determinants of credit rationing and/or overlending. This is achieved through multivariate analysis of the banking errors' occurrence. We use several measurements, linked to the starter, the project or the industry, and look for their coincidence with credit rationing and/or overlending. Most significant factors enter into a consistent relation: when they are positively (negatively) associated with credit rationing, they are negatively (positively) associated with overlending. 
All our analyses are carried on firm level qualitative and quantitative data produced by the French National Institute of Statistics and Economic Studies (INSEE). The dataset relates to an original, mandatory survey for a cohort of new firms set up, or taken over, in 1994 in France, with a follow-up survey three years later. Although it might appear a bit historic, this panel survey opens avenues for applied financial research. It is indeed exceptional to have access to information all together on the demand of credit by new firms, on their actual access to banking loans and on their more or less fortunate situation three years after birth (Did they survive or not?). Our results show that, contrary to what is usually thought, overlending can be a much more common occurrence than credit rationing for firms on the credit market. Our results therefore suggest that De Meza-Webb model is a more realistic view than the Stiglitz-Weiss credit rationing theory.

The remaining of the paper is structured as follows. In section 2, we present the different views concerning the influence of asymmetric information on the access of firms to credit. We show that this imperfect information can drive bankers to make two different kinds of bad, erroneous decisions, not only credit rationing but overlending as well. Section 3 presents the methodology and introduces the way bankers' errors are identified. Section 4 introduces the data and section 5 gives and discusses the main results. The paper ends with some concluding remarks and implications.

\section{2- Asymmetric information and bankers' errors in the decision to grant credit}

2.1. The dominant theoretical view: asymmetric information drives credit rationing

There is a longstanding belief in both academic literature and policy circles that small firms are unable to obtain sufficient banking loans. This view of a small business credit gap is indeed very old and is largely shared by the scientific community. Classical economists, like Turgot $(1766,1770)$ and Smith (1776), supported the premise that usury laws were responsible for the regular shortages of credit, thereby limiting economic development and market expansion. Keynes (1930) emphasized the existence of unsatisfied borrowers on the credit market. New Keynesian economists contributed greatly to this analysis of financial constraints (Mankiw and Romer 1991a and 1991b). They stress that the role of nominal rigidities -institutional barriers like usury laws and/or habits in the banking sector- explain disequilibrium on the credit market.

The contribution of Stiglitz and Weiss (1981) appears as the culmination of credit rationing theory. The authors directly link credit rationing to asymmetric information that does not depend on any exogenous factors. In Stiglitz and Weiss (1981), all entrepreneurs launching projects require the same external finance and have the same mean return, differing only in risk. 
The individual characteristics of entrepreneurs are privileged information owned by entrepreneurs and imperfectly shared with outside investors. In this model, bankers only know the distribution of entrepreneurs' characteristics. Consequently, the risk of projects cannot be easily and perfectly assessed. Bankers may not be able to differentiate adequately between high risk and low risk debtors. Moreover, once loans are granted, borrowers may not be able to perfectly monitor firms. In all these cases, increasing the interest rate may be disastrous. A rise in the interest rate would drive the "best" firms (lower risks) to refuse loans proposals that they consider too costly (adverse selection). Additionally, it may incite firms to launch riskier projects, leading to an excessively risky portfolio (moral hazard). Ultimately, because of these informational imperfections, bankers may prefer not to lend credit at all and equilibrium on the credit market may arise with rationing.

The scientific community has been largely impressed by the quality of this demonstration. Yet finding strong empirical evidence of credit rationing is not easy.

\subsection{The difficult empirical identification of credit rationing}

Several empirical strategies have been used in order to assess the actual extent of credit rationing. Quite all emphasize the difficulty to test the credit rationing theory and lots of them show that, despite common ideas, credit rationing is rather limited.

A first strand of literature use proxies to identify credit rationing. Within the disequilibrium credit rationing theory, it is the rise of interest rate that was supposed to reveal it. Since endogenous credit rationing theory demonstrates the disability of interest rates to equilibrate credit market, empirical researches have introduced other proxies, in particular cash flows and internal finance. This literature supposed that investment of financially constrained firms displays an "excess sensitivity" to movements in cash flow (Fazzari, Hubbard and Petersen, 1988). This idea is very popular despite the critical view taken by Kaplan and Zingales (1997). Reconsidering the firms identified by Fazzari, Hubbard, and Petersen (1988) as having unusually high investment-cash flow sensitivities, they find that firms that appear less financially constrained exhibit significantly greater sensitivities than firms that appear more financially constrained. They criticize the usefulness of investment-cash flow sensitivities for detecting financing constraints and they also stress the fact that financial constraints may not be as strong as Fazzari, Hubbard and Petersen (1988) suggest ${ }^{1}$. Concerning new firms, a large strand of the empirical literature derives from a significant positive relationship between entrepreneur's wealth and the probability to become self-employed that start-ups might suffer from capital gap (see, as

\footnotetext{
${ }^{1}$ More recently, Becchetti, Castelli and Hasan (2010) contribute to this debate by considering a sample of small and medium sized firms.
} 
the seminal paper, Evans and Jovanovic, 1989; this literature also includes Fairlie, Krashinsky, 2012, Nykvist, 2008, Cagetti, De Nardi, 2006). This interpretation is strongly criticized by Cressy (1996), who supports the idea that the correlation between financial capital and the survival of new firms is spurious and that the treatment of endogeneity between the determinants of banking loans and those of entrepreneurial activity mainly stresses the role of human capital ${ }^{2}$.

A second strand of the empirical literature is directly inspired by the disequilibrium theory. It assesses the existence of credit rationing at the microlevel by estimating and comparing the notional demand and supply of credit. Using this methodology on French data, Kremp and Sevestre (2013) show that supply of credit is as a whole superior to demand. They conclude that SMEs do not appear to have been strongly affected by credit rationing even after the financial crisis of 2008. Full rationing, i.e. the percentage of firms with no loan, is always inferior to $2 \%$ for all SME on the period 2007-2010 (4.10\% for young firms).

A third strand use surveys to measure the probability of firms applying for credit to be denied for banking loans (for example, Guiso, 1998, Blumberg, Letterie, 2007, Piga, Atzeni, 2007). As these investigations are unable to distinguish creditworthy firms from the others, credit rationing is most often largely overestimated (Levenson and Willard, 2000). These studies measure more financial constraints than credit rationing. Levenson and Willard (2000) add that, to be complete, credit rationing should consider the case of creditworthy firms that do not apply for banking loans but should have do it, i.e. "the discouraged firms". Trying to correct these two drawbacks, Levenson and Willard (2000) find that credit rationing is rather limited as it just concerns a maximum of 6.36 percent of small firms in the US during the late eighties.

While empirical studies on credit rationing and financial constraints are multiplying, a controversy has emerged at the theoretical level: imperfect information can lead not only to credit rationing but to overlending as well.

\subsection{The alternative view: informational asymmetries can drive to overlending}

De Meza and Webb (1987, 2000, and 2006) and De Meza (2002) broke the consensus in the scientific community concerning the consequence of asymmetric information on the credit market. They show, by marginally changing some hypotheses in the seminal model of Stiglitz and Weiss (1981), that asymmetric information can produce overlending.

\footnotetext{
2 "Provision of finance is demand-driven, with banks supplying funds elastically and business request governing take-up. Firms self-select for funds on the basis of the human capital endowments of the proprietors with 'better' business more likely to borrow. A reason why others have seemingly identified start-up debt-gaps may be the failure to test a sufficiently rich empirical model" (Cressy, 1996, p. 1253).
} 
In De Meza and Webb (1987), like in Stiglitz and Weiss (1981), all projects require the same initial investments and the same level of external finance. In both models bankers are assumed to have no prior information on entrepreneurs' characteristics, but they know the distribution of the characteristics of these. Additionally, banks are risk-neutral profit maximizers. Contrary to Stiglitz and Weiss (1981), the expected return differs between projects. Entrepreneurs differ from each other in expected return and not in risk. This change in the hypotheses has serious consequences. De Meza and Webb (1987) identify no further credit rationing. On the contrary, they demonstrate the possible existence of over-lending; opaque firms can benefit from an excess of credit.

By combining the assumption that entrepreneurs differ in intrinsic quality (and not only in risk) with a moral hazard problem, De Meza and Webb (2000) show, as well, that even a creditrationing equilibrium may involve excessive lending. Rationing occurs as a result of moral hazard and can coexist with overinvestment due to heterogeneous types of agents. If banks randomly screen applicants for credit, the result may be more lending than the optimal situation under full information ${ }^{3}$.

To sum up, asymmetric information makes a fringe of agents unsatisfied on credit market. Due to asymmetric information, bankers cannot perfectly discriminate between "good" and "bad" firms. In this context, they can make errors; either they refuse credit to "good" firms (credit rationing) or they finance "bad" ones (overlending). However the empirical literature principally focuses on credit rationing. Overlending is only mentioned by Cressy (1996) and has never been the focus of an empirical work. In the following we attempt to fill this gap.

\section{3- Research methodology: identification of bankers' errors}

The first objective of this study is to identify the errors made by bankers when they screen applicants for credit in the context of a credit market with asymmetric information. We consider the two polar opposite cases directly derived from the theoretical literature mentioned above: credit rationing and overlending.

Credit rationing corresponds to the situation of firms that are denied credit by banks, even though they are not so $\mathrm{bad}^{4}$. Overlending corresponds to the situation of firms that get banking

\footnotetext{
${ }^{3}$ De Meza and Webb (2006) also criticize the implicit hypothesis in Stiglitz and Weiss (1981) that the marginal cost of funds to the borrowers is infinite. They show that, under this hypothesis, entrepreneurs have an overwhelming incentive to cut their loans in order to avoid rationing. Following this argument, De Meza and Webb finally show that, in the theoretical framework of Stiglitz and Weiss, credit rationing would only emerge for indivisible projects when delay causes sufficient deterioration.

${ }^{4}$ The definition and its development are given with reference to full credit rationing, i.e. credit is refused, that corresponds to the measurement used within our estimations.
} 
loans, even though they are not so good. Due to asymmetric information, banks cannot perfectly assess the quality of applicants for credit, thus they cannot perfectly discriminate between good and bad firms.

Banks grant credit to firms that they consider being good. It is indeed important to consider creditworthy firms to assess credit rationing. When empirical investigations consider the cases of firms that are just denied for credit they do not measure credit rationing but credit constraints: as mentioned by Levenson and Willard (2000), when one does this, credit rationing is overestimated. To assess credit rationing we must focus on firms that are denied for credit although creditworthy. Bankers only distribute credit to firms whose default rates are supposed to be low. For new firms, rates of credit default are strongly correlated with failure rates. Bankers indeed assess the new firms' repayment ability by considering their ability to survive. They give credit to firms that are supposed to be able to survive. They reject the credit application if the expected risk of default/failure is high. Consequently, estimating bankers' errors in granting credit (or not) can be approximated by the gap between the anticipated firm failure (or survival) and the real firm failure (or survival).

Bankers' errors are identified in Table 1 by crossing, on one hand, information on the decision of bankers at firm birth (acceptance or refusal of the credit demand), directly linked to the bank anticipated future of the firm (survival or failure) and, on the other hand, information on the real status of firms (survival or failure) several years after the application for credit.

\section{Table 1. Imperfect information and bankers' errors}

\begin{tabular}{|l|c|c|}
\hline \multicolumn{1}{|c|}{ Ex post quality } & Good (Survival) & Bad (Failure) \\
Decision of bankers (Ex ante quality) & & Overlending \\
\hline Credit is accepted (expected survival) & Good discrimination & Good discrimination \\
\hline Credit is refused (expected failure) & Credit rationing & \\
\hline
\end{tabular}

Credit rationing error corresponds to the situation where firms are denied for credit although they should not, i.e. although they survive. By contrast, overlending error corresponds to the situation where firms get credit although they should not, i.e. although they fail.

After identifying the share of credit rationing and overlending, we look for their factors by using logistic models. In the credit rationing empirical model, the endogenous variable is equal to 1 if bankers ration credit and zero otherwise. In the overlending model, the endogenous variable is equal to 1 if overlending is identified and zero otherwise. All estimated models include several variables characterizing the firm and its context: origin, branch of industry, financial public aid, 
size, and investment. Other variables describe the entrepreneur. These comprise the entrepreneur's human capital measured through his (or her) previous professional occupation, level of education (diploma), skills acquired during previous activity, length of the experience in the same branch of activity, size of the firm in which experience was acquired, main motivation for the business to be established, present managing experience, and the number of firms set up before. We also include the entrepreneur's social capital linked to entrepreneurship and business ownership (family antecedents, or friends), and other individual characteristics (gender, age and nationality). A brief presentation of the expected relations between credit rationing or overlending and the variables entering the estimated models is given in the next section.

\section{4- Data}

All empirical analyses appearing herein are conducted on individual firm data drawn from the New Enterprise Information System (SINE) produced by the French National Institute of Statistics and Economic Studies (INSEE). The SINE dataset does not refer to the general entrepreneurial intention in the French population, but to entrepreneurial projects that are formalized through new firms. As a consequence, entrepreneurial intentions that are aborted due to a lack of financial resources are not taken into account. The SINE dataset concerns firms and not potential entrepreneurs. Accordingly, our analyses concern existing new firms applying for credit and not potential entrepreneurs that anticipate either receiving or being denied credit. The point is important as firm financing conditions are here considered.

In this study, we focus on the representative cohort of new firms established in 1994. We selected this cohort and the corresponding survey because it gives specific information that was no longer available afterwards for more recent cohorts about the potential quantitative constraint that new firms encountered when applying for a bank loan at birth. We use two questions from the survey to build the variable refusal (or acceptance) of a bank loan: To finance your project did you apply for a bank loan? If yes, did you obtain this bank loan? The combination of questions makes possible the identification of constrained firms that applied for banking credit but were denied $\mathrm{it}^{5}$.

In the framework of the INSEE SINE project, each cohort is the object of several surveys resulting in a panel dataset. Concerning the cohort of new firms set up in 1994, the first-wave survey (SINE 94-1) was conducted among a sample of 30,778 firms that were established or

\footnotetext{
${ }^{5}$ These questions on the access of new firms to credit at birth were removed from the following surveys carried out in 1998 and 2002. In SINE 2006 and 2010, new firms were questioned more broadly on their difficulties accessing credit, without determining if they finally succeed in accessing to banking loans and if financial difficulties are based on a quantitative restrictive supply of credit or an excessive cost of debt.
} 
taken over during the first half of 1994 , and survived at least for one month. The sample ${ }^{6}$ is representative of the total population, which consisted of 96,407 new firms belonging to the private productive sector, active in the fields of industry, building, trade and services. A secondwave survey (SINE 94-2), was carried out in 1997; it provides information about the status of the same firms three years after birth (still running or closed down).

For the sake of consistency, we consider only new firms that were active in the same field over the entire period, i.e. without change of (branch of) activity during the period; with unvarying legal status ${ }^{7}$; and established by individuals in Metropolitan France, meaning that firm subsidiaries and French overseas department are excluded. Finally we consider only new firms with banking relationships, i.e. new firms that have applied for banking loans, at their birth. Our sample consists of 8,855 units, representing 22,760 new firms ${ }^{8}$.

\footnotetext{
${ }^{6}$ It is a compulsory survey that obtained a $98.8 \%$ rate of reply. The sample was built by randomly drawing out samples from 416 (2x8x26) elementary strata: origin (start-up or takeover: 2 modalities), branch (8 modalities) and localization (22 French regions plus 4 overseas départements).

${ }^{7}$ Very often, when a firm changes its status, it has important financial consequences; it is no longer the same firm. For example, the shift from the limited liability status of SARL (Société Anonyme à Responsabilité Limitée) to a SA (Société Anonyme) status, which is also a limited liability's status, means also a large increase of the social capital (mandatory private equity) from 7623 euros to 38112 euros, as well as a large increase of the board, which encompasses a greater number of members (at least 7 , versus 2 for firms with SARL status). Taking a specific case from the SINE dataset, we found that the change of status was also accompanied by a huge and quick increase of the numbers of employees (from 7-8 to more than 22). The change of status was also accompanied by a change of branch of activity (from $74.1 \mathrm{G}$, advices for business and management, to $748 \mathrm{~K}$, secondary services in the production).

${ }^{8}$ The exploitation of the database involves the use of a weight variable which is the reverse of the draw rate per branch, per region and per origin.
} 
Table 2: Descriptive statistics

\begin{tabular}{|c|c|c|}
\hline $\begin{array}{c}\text { Explanatory variable/Reference modality } \\
\text { Number of observations: } 22760\end{array}$ & Modalities & Mean \\
\hline Weight & ns & $5.156($ Std dev 5.6, $\min 1, \max 22)$ \\
\hline Bank loan asked/Accepted & Refused & 0.123 \\
\hline Origin/Start-up & Takeover & 0.418 \\
\hline \multirow{7}{*}{$\begin{array}{l}\text { Branch of Activity/ } \\
\text { Trade }\end{array}$} & Agriculture and food industry & 0.041 \\
\hline & Manufacturing & 0.075 \\
\hline & Transportation & 0.052 \\
\hline & Construction & 0.104 \\
\hline & Catering & 0.163 \\
\hline & Household services & 0.130 \\
\hline & Services to firms & 0.105 \\
\hline Public financial aid/Non obtained & Obtained & 0.404 \\
\hline \multirow{3}{*}{$\begin{array}{c}\text { Initial size of the firm/ } \\
\text { No employee }\end{array}$} & 1 employee & 0.195 \\
\hline & $2-5$ employees & 0.208 \\
\hline & +5 employees & 0.046 \\
\hline \multirow{7}{*}{$\begin{array}{c}\text { Total amount of money invested at the } \\
\text { beginning/ } \\
\mathbf{7 6 2 3}-\mathbf{1 5 2 4 4} \text { euros }\end{array}$} & Less than 1525 Euros & 0.048 \\
\hline & $1525-3811$ Euros & 0.082 \\
\hline & $3812-7622$ Euros & 0.130 \\
\hline & $15245-38112$ Euros & 0.232 \\
\hline & $38113-76225$ Euros & 0.148 \\
\hline & $76226-152450$ Euros & 0.095 \\
\hline & +152450 Euros & 0.063 \\
\hline \multirow{2}{*}{$\begin{array}{l}\text { Nationality/ } \\
\text { French }\end{array}$} & European foreigner & 0.029 \\
\hline & Non-European foreigner & 0.029 \\
\hline Gender/Woman & Man & 0.697 \\
\hline \multirow{6}{*}{$\begin{array}{l}\text { Age of the entrepreneur/ } \\
\mathbf{3 0}-\mathbf{3 5} \text { years old }\end{array}$} & -25 years old & 0.082 \\
\hline & $25-30$ years old & 0.182 \\
\hline & $35-40$ years old & 0.173 \\
\hline & $40-45$ years old & 0.160 \\
\hline & $45-50$ years old & 0.129 \\
\hline & +50 years old & 0.078 \\
\hline \multirow{7}{*}{ Previous professional status Employee } & Craftsman & 0.106 \\
\hline & Manager & 0.045 \\
\hline & Supervisor worker & 0.056 \\
\hline & Middle management position & 0.070 \\
\hline & Executive & 0.151 \\
\hline & Worker & 0.169 \\
\hline & Student & 0.085 \\
\hline \multirow{3}{*}{$\begin{array}{l}\text { Previous occupation of the entrepreneur/ } \\
\text { Labor force }\end{array}$} & Short term unemployed & 0.321 \\
\hline & Long term unemployed & 0.159 \\
\hline & Non-working & 0.085 \\
\hline \multirow{4}{*}{$\begin{array}{l}\text { Level of diplomal } \\
\text { Intermediate level }\end{array}$} & No diploma & 0.095 \\
\hline & Secondary school diploma & 0.162 \\
\hline & Till two years at university & 0.098 \\
\hline & $\begin{array}{c}\text { From three years and more at } \\
\text { university }\end{array}$ & 0.100 \\
\hline \multirow{3}{*}{$\begin{array}{c}\text { Experience in the same branch of activity/ } \\
\text { No experience }\end{array}$} & Close vocational experience & 0.137 \\
\hline & Different experience & 0.214 \\
\hline & Close experience for the partner & 0.043 \\
\hline \multirow{3}{*}{$\begin{array}{l}\text { Length of the experiencel } \\
\text { More than } 10 \text { years }\end{array}$} & No experience & 0.020 \\
\hline & 3 years experience & 0.120 \\
\hline & $3-10$ years experience & 0.250 \\
\hline \multirow{6}{*}{$\begin{array}{l}\text { Size of the firm in which the experience was } \\
\text { acquired/ } \\
\text { Between } 4 \text { and } 9 \text { employees }\end{array}$} & Less than 3 employees & 0.180 \\
\hline & Between 10 and 49 employees & 0.125 \\
\hline & Between 50 and 99 employees & 0.033 \\
\hline & Between 100 and 199 employees & 0.023 \\
\hline & Between 200 and 499 employees & 0.020 \\
\hline & More than 500 employees & 0.046 \\
\hline Entrepreneurial milieu/Family or friends & No & 0.255 \\
\hline \multirow{4}{*}{$\begin{array}{l}\text { Main motivation to set up his firm/ } \\
\text { Taste for entrepreneurship }\end{array}$} & Start for new idea & 0.072 \\
\hline & Catch an opportunity & 0.257 \\
\hline & Start for necessity & 0.130 \\
\hline & Example of the surrounding & 0.033 \\
\hline Other current entrepreneurial involvement/No & Yes & 0.108 \\
\hline \multirow{3}{*}{$\begin{array}{l}\text { Previous setting up of new firms/ } \\
\text { No }\end{array}$} & 1 startup & 0.115 \\
\hline & 2 or 3 startups & 0.054 \\
\hline & +4 startups & 0.012 \\
\hline
\end{tabular}


The dataset is mainly constituted of new firms startups (around 60\%; the complement being takeovers). The initial size of firms, measured by the number of employees, is rather low, as is the case for the initial amount of money initially invested into the business - only $15.8 \%$ invested more than 76226 euros (see Table 2).

Covariates have been chosen for their relevance according to the acceptance of a bank loan and the survival of the firm. On this regard, gender is included because access to networks, specifically here financial networks, is reported to constitute a serious impediment to female entrepreneurship (Bel, 2009; Nelson and Vosmek, 2014). The mode of entry, by seetting up a new firm or by takeover, gives information about the duration of the firm and the probability to see its bank loan accepted; the probability being generally higher in the case of takeover (Bastié et al., 2013). When the setting-up of the firm is motivated by the willingness to escape unemployment, the new firm appears more prone to exit as in Abdesselam et al. (2004). Exit is also reported to be positively correlated with a low level of education, being a female or being of foreign origin (Bhattacharjee et al., 2008). Because entrepreneurship can be a way for foreign people to circumvent discrimination in the labor market and because it is more difficult for them to integrate networks, we assume that, like female entrepreneurship, they suffer from a lack of access to finance. The level of diploma of the business owner is usually associated with a longer firm life span (Bates, 1990, 2005, Parker and van Praag, 2006), except when it is associated with a previous unemployment position - then the level of diploma is not a good predictor of the survival of the new firm (Bhattacharjee et al., 2008). Still with respect to the business owner, a strong expertise derived from different kinds of experience is likely to increase the firm survival. We may cite here knowledge of the sector, previous functional experience in a managerial position (Fairlie and Robb, 2006), former entrepreneurial experience by having already started a business or by having been close to the decision-making process inside a small business. By exploring the SINE dataset, Bhattacharjee et al. (2008) Bhattacharjee et al. (2008) have shown that having some experience acquired in a small business is translated in a longer life span; but this is not the case for having previous entrepreneurial experience. Evans and Leighton (1989, p. 521) have noticed the greater propensity to entrepreneurship of "unemployed workers, lowerpaid wage workers and men who have changed jobs a lot". The initial size of the project that is launched is positively associated with its survival probability (Audretsch and Mahmood, 1995; Geroski et al., 2002). To hire an employee at the outset of the firm may be a good signal but it may also be a weakness for the duration of the firm in the very first stages of development (Désiage et al., 2011). Unfortunately, the SINE dataset does not provide any information about the business owner's private assets and possible pledge of collaterals. This is obviously a limit of 
the estimated models. However, we note that collected evidence by Cressy (1996) suggests that business owner's private assets enter in a non-significant relation with business survival when covariates for human capital - that is proxied here by several variables - are included into the estimated model. 


\section{5- Results}

\subsection{The determinants of the bankers' decision}

Table 3 reports factors that influence the decision of bankers to grant credit to new firms. The factors that positively influence the decision to grant credit demand are, among firms' characteristics, to take over an existing firm rather than to start ex nihilo a new business; to receive public financial aid; and to have high financial capital at start (more than 15,245 €). Among entrepreneurs' characteristics, the factors that make it likely to receive a bank loan are some previous (before start) professional status of the business-owner, i.e. having been craftsman or supervisor (compared to having been an employee), and having experience in a branch close to the one of the new venture rather than having no experience. On the contrary, the factors that negatively influence the decision to grant credit demand include being active in the branch Services to firms (Trade being the reference modality); having employees; having a low level of financial capital (less than 7,623€). Entrepreneur's characteristics that negatively affect the grant decision include being foreign; male; formerly unemployed or without activity; having been, previously to the start, a worker, a middle manager or executive (compared to having been an employee); to have a level of education corresponding at most to a two years Bachelor degree; to create the firm by necessity motive; not benefiting from an entrepreneurial milieu and having antecedents in the setting-up of new firms.

Our results are consistent with previous studies on the determinants of banking loans received by new firms; in particular, regarding the mode of entry (Bastié et al., 2013) and the role of initial financial capital in increasing access to credit to new firms (Cagetti, De Nardi, 2006; Nykvist, 2008; Fairlie, Krashinsky, 2012). Having obtained public financial aid is also a factor facilitating access. The role played by the business-owner's human capital, in particular linked to the professional and educational background, is more ambiguous: access to credit appears to decrease to a certain point with the level of diploma whereas past experience in the same branch of activity plays a positive role. Having some previous entrepreneurial experience is negatively linked with access to credit. We might have expected experience being appreciated by bankers. According to our results, it is not the case; on the contrary. A reason could be that bankers include in their decision making that previous entrepreneurial experience does not necessarily mean entrepreneurial learning and enhancement of firm performance but rather signals bad risks. Perhaps, it is going too far. In a study about a large sample of UK and Wales start-ups, Frankish et al. (2013, p. 102) find that prior business experience as an owner has "no substantial influence" on survival rates. 
Table 3. The decision of bankers to grant credit

\begin{tabular}{|c|c|c|}
\hline Number of observations: 22760 & Modalities & $\begin{array}{c}\text { Model 1 Grant credit } \\
\text { Bank loan asked and accepted: } \\
\text { (19959 observations) }\end{array}$ \\
\hline Explanatory variable/Reference modality & Intercept & $2.305 * * *$ \\
\hline Origin/Start-up & Takeover & $0.649 * * *$ \\
\hline \multirow{7}{*}{$\begin{array}{l}\text { Branch of Activity/ } \\
\text { Trade }\end{array}$} & Agriculture and food industry & $1.124 * * *$ \\
\hline & Manufacturing & 0.120 \\
\hline & Transportation & $0.400^{* * *}$ \\
\hline & Construction & $0.178^{*}$ \\
\hline & Catering & $0.534 * * *$ \\
\hline & Household services & $0.864 * * *$ \\
\hline & Services to firms & $-0.236 * *$ \\
\hline Public financial aid/Non obtained & Obtained & $0.736 * * *$ \\
\hline \multirow{3}{*}{$\begin{array}{c}\text { Initial size of the firm/ } \\
\text { No employee }\end{array}$} & 1 employee & $-0.102 *$ \\
\hline & $2-5$ employees & $-0.182 * * *$ \\
\hline & +5 employees & $-1.014 * * *$ \\
\hline \multirow{7}{*}{$\begin{array}{l}\text { Total amount of money invested at the beginning/ } \\
\mathbf{7 6 2 3}-\mathbf{1 5 2 4 4} \text { euros }\end{array}$} & Less than 1525 euros & $-1.018 * * *$ \\
\hline & $1525-3811$ euros & $-0.514 * * *$ \\
\hline & $3812-7622$ euros & $-0.184 * * *$ \\
\hline & $15245-38112$ euros & $0.286^{* * *}$ \\
\hline & $38113-76225$ euros & $0.701 * * *$ \\
\hline & $76226-152450$ euros & $1.028 * * *$ \\
\hline & +152450 euros & $2.539 * * *$ \\
\hline \multirow{2}{*}{$\begin{array}{l}\text { Nationality/ } \\
\text { French }\end{array}$} & European foreigner & $-0.306 * *$ \\
\hline & Non-European foreigner & $-1.315 * * *$ \\
\hline Gender/Woman & Man & $-0.252 * * *$ \\
\hline \multirow{6}{*}{$\begin{array}{l}\text { Age of the entrepreneur/ } \\
\mathbf{3 0}-\mathbf{3 5} \text { years old }\end{array}$} & -25 years old & $0.183 * *$ \\
\hline & $25-30$ years old & $0.256^{* * *}$ \\
\hline & $35-40$ years old & 0.083 \\
\hline & $40-45$ years old & $0.316^{* * *}$ \\
\hline & $45-50$ years old & $0.140^{*}$ \\
\hline & +50 years old & $0.197 * *$ \\
\hline \multirow{7}{*}{ Previous professional status Employee } & Craftsman & $0.354 * * *$ \\
\hline & Manager & -0.151 \\
\hline & Supervisor worker & $0.219 * *$ \\
\hline & Middle management position & $-0.182 * *$ \\
\hline & Executive & $-0.137^{*}$ \\
\hline & Worker & $-0.154 * *$ \\
\hline & Student & -0.069 \\
\hline \multirow{3}{*}{$\begin{array}{c}\text { Previous occupation of the entrepreneur/ } \\
\text { Labor force }\end{array}$} & Short term unemployed & $-0.830 * * *$ \\
\hline & Long term unemployed & $-1.111 * * *$ \\
\hline & Non-working & $-0.686 * * *$ \\
\hline \multirow{4}{*}{$\begin{array}{l}\text { Level of diplomal } \\
\text { Intermediate level }\end{array}$} & No diploma & 0.007 \\
\hline & Secondary school diploma & $-0.154 * *$ \\
\hline & Till two years at university & $-0.210 * * *$ \\
\hline & $\begin{array}{l}\text { From three years and more at } \\
\text { university }\end{array}$ & -0.047 \\
\hline \multirow{3}{*}{$\begin{array}{c}\text { Experience in the same branch of activity/ } \\
\text { No experience }\end{array}$} & Close vocational experience & $0.254 * * *$ \\
\hline & Different experience & $-0.209 * *$ \\
\hline & Close experience for the partner & $-0.213^{*}$ \\
\hline \multirow{3}{*}{$\begin{array}{l}\text { Length of the experiencel } \\
\text { More than } 10 \text { years }\end{array}$} & No experience & $-0.358 * *$ \\
\hline & 3 years experience & $-0.421 * * *$ \\
\hline & $3-10$ years experience & $-0.141 * *$ \\
\hline \multirow{6}{*}{$\begin{array}{l}\text { Size of the firm in which the experience was } \\
\text { acquired/ } \\
\text { Between } 4 \text { and } 9 \text { employees }\end{array}$} & Less than 3 employees & 0.006 \\
\hline & Between 10 and 49 employees & $0.158^{* * *}$ \\
\hline & Between 50 and 99 employees & $-0.471 * * *$ \\
\hline & Between 100 and 199 employees & $0.273^{* * *}$ \\
\hline & Between 200 and 499 employees & $-0.588 * * *$ \\
\hline & More than 500 employees & $-0.301 * *$ \\
\hline Entrepreneurial milieu/Family or friends & No & $-0.148 * * *$ \\
\hline \multirow{4}{*}{$\begin{array}{l}\text { Main motivation to set up his firm/ } \\
\text { Taste for entrepreneurship }\end{array}$} & Start for new idea & -0.091 \\
\hline & Catch an opportunity & 0.055 \\
\hline & Start for necessity & $-0.481 * * *$ \\
\hline & Example of the surrounding & 0.014 \\
\hline Other current entrepreneurial involvement/No & Yes & $-0.206 * *$ \\
\hline \multirow{3}{*}{$\begin{array}{c}\text { Previous setting up of new firms/ } \\
\text { No }\end{array}$} & 1 startup & $-0.391 * * *$ \\
\hline & 2 or 3 startups & $-0.512 * * *$ \\
\hline & +4 startups & $-0.759 * * *$ \\
\hline LR ratio: null hypothesis $\beta=0$ & \multirow{2}{*}{ DF: Degree of Freedom: 64} & $2547.515 * * *$ \\
\hline Percent Concordant & & $75.3 \%$ \\
\hline
\end{tabular}

Note: $*$ (respectively $* *, * * *)$ means the rejection of the null hypothesis for a $10 \%$ threshold (respectively $5 \%, 1 \%$ ). 


\subsection{Overlending is more frequent than credit rationing}

The distribution of new firms with credit demand according to the decision of bankers (being correct or erroneous), on one hand, and the status of the firm three years after its start (being still alive or dead), on the other hand, allows to distinguish four cases including credit rationing and overlending. The distribution is reported in Table 4. We find erroneous decision, either credit rationing or overlending, occurred in $35.49 \%$ of the sample. Credit rationing only concerns $5.03 \%$ of the total sample, and overlending $30.47 \%$. These findings support the theory of De Mezza and Webb (1987) that bankers would grant too much credit taking into account the final risk of default among new firms. This result contradicts the notion of a banking credit constraint that is usually postulated in the literature on small firms. Out of the total population of 22,760 firms that applied for a bank loan, only 2,801 firms (1143+1658) were denied banking loans, indicating that the rate of refusals is quite low $(12.31 \%)$ whereas the rate of firms that ceased operations is $37.75 \%$.

Table 4. Distribution of new firms with credit demand

\begin{tabular}{|c|c|c|c|}
\hline $\begin{array}{l}\text { Ex post quality of firm } \\
\text { Ex ante discrimination }\end{array}$ & Good (Alive) & Bad (Closed) & Total \\
\hline Errors & $\begin{array}{c}\text { Banking loan denied } \\
\text { Credit rationing } \\
1143 \\
5.03 \% * / 14.15 \% * * / 8.08 \% * * *\end{array}$ & $\begin{array}{c}\text { Banking loan accepted } \\
\text { Overlending } \\
6935 \\
30.47 \% * / 85.85 \% * * / 80.71 \% * * *\end{array}$ & $\begin{array}{c}\text { Errors } \\
8078 \\
35.49 \% *\end{array}$ \\
\hline Non Errors & $\begin{array}{c}\text { Banking loan accepted } \\
\text { Non errors } \\
13024 \\
57.22 \% * / 88.71 \% * * / 91.92 \% * * *\end{array}$ & $\begin{array}{c}\text { Banking loan denied } \\
\text { Non errors } \\
1658 \\
7.28 \% * / 11.29 \% * * / 19.29 \% * * *\end{array}$ & $\begin{array}{l}\text { Non errors } \\
14682 \\
64.51 \% *\end{array}$ \\
\hline Total & $\begin{array}{c}14167 \\
62.25 \% *\end{array}$ & $\begin{array}{c}8593 \\
37.75 \% *\end{array}$ & $\begin{array}{c}22760 \\
100.00 \% *\end{array}$ \\
\hline
\end{tabular}

Lecture of the table: $* \%$ of the cell in the total sample, $* * \%$ of the cell in the line, $* * * \%$ of the cell in the column

The collected evidence confirms that overlending is much more frequent than credit rationing. The analysis given by De Mezza and Webb (1987) appears to be much more realistic than Stiglitz and Weiss (1981). Remarkably, our results regarding credit rationing are in line with previous studies that assess the frequency of credit rationing on the French credit market. Using approaches based on disequilibrium econometrics, they all stress that credit rationing concerns a minority of borrowers (Cieply, Paranque, 1998; Aubier, Cherbonnier, 2007; Kremp, Sevestre, 2013). For the last crisis period (2007-2012), Kremp and Sevestre (2013) show that the proportion of firms partially credit rationed is around $7 \%$ and the proportion of firms experiencing full rationing is around $2 \%$. For young firms, and therefore for a sample of firms in 
a situation comparable to ours, partial rationing is equal to $10.3 \%$ and full rationing concern $4.1 \%$ of firms. The authors stress as well the proximity of their results with those given by surveys carried out on credit rationing in France. So doing, they reckon an average probability of credit rationing that is around $8 \%$ (8.5\% for partial rationing and $7.9 \%$ for full rationing), which is very close to our estimations. We have not identified any empirical study that measures the proportion of firms in overlending situation and, to the best of our knowledge, the conducted analysis is the first to stress that excess of credit is much more frequent than credit rationing on the credit market.

\subsection{Limits and robustness analysis}

Our findings highlight the relatively low frequency of credit rationing on the credit market. Credit rationing would have indeed affected less than 6\% of new firms in France in 1994, whereas overlending would have affected $30.5 \%$ of our sample. Figures may appear quite appealing. At first glance, they suggest that banks would consider minimizing credit demand rejection and accepting the loss of funds due to the borrowing firm's failure in three cases out of ten being an acceptable strategy. To explain the wide spread between the frequencies of each error type, we have first to emphasize and to keep in mind that overlending by banks does not mean total loss of their grant with the firm failure. Within the pecking order of creditors, banks are indeed regularly among the first to be paid back. Moreover, they can generally count on collaterals. These elements tend to reduce drastically the adverse consequences of overlending from the banks' viewpoint. Second, we need to account for three potential biases:

-The cohort of new firms surveyed by INSEE was launched in 1994. This year corresponds to a year of recovery taking place after the 1993 recession when the French GDP decreased by $1 \%$. We cannot exclude that the global atmosphere became more favorable to activity inducing bankers to be less conservative in their assessment and decision regarding new firms' investments and loan demands, whereas existing firms were more inclined to selffinancing their projects (Banque de France, Exercice 1994).

-The exploited dataset refers to new firm projects that were actually undertaken but not those that were aborted due to bank loan refusals. Regarding the latter, it must be noticed that some could have been successful; their absence may thus lead to an underestimation of financial constraints. In this study, credit rationing only concerns firms that applied for credit. However, some entrepreneurs may end their new firm project because they anticipate the refusals of banks. Less radically, some firms may grow more slowly because, anticipating the bankers' refusal, entrepreneurs do not ask for credit. In these two cases of self-credit-rationing, entrepreneurs are 
said to be discouraged (Kon, Storey, 2003). As they do not ask for credit, they cannot be identified within the INSEE dataset. We only observe that, out of a population of 66,873 new firms established in 1994, only 34\% (22,760 firms) asked for credit at their birth. This relatively low proportion could be connected to the self-credit-rationing phenomenon, but we cannot say more about it.

-Finally, receiving a bank loan may extend the life span of firms significantly. To assess the impact of obtaining a credit on the firm's survival, we use a logistic model with the firm status (alive or closed down) as the binary endogenous variable (equal to 1 when firms are still alive three years after founding; equal to 0 otherwise) and the access to credit among exogenous variables. The results, reported in Table 5, confirm the view that receiving the bank support is an important determinant of the likelihood of new firms to survive. Other noteworthy positive factors, i.e. having received public financial aid, the relative importance of initial invested funds and having an experience in the same branch of activity greater than 10 years, emphasize the importance of financial conditions, financial and human capital at start, from the banker viewpoint; an observation in line with other empirical contributions (see e.g. Cressy, 1996).

Remarkably, we detect as well an asymmetric efficiency in bankers' decisions according to the ex post new firms' statute. On one hand, bankers appear to discriminate quite well good firms. In the population of firms that were still alive three years after birth, we observe a very high rate $(91.92 \%)$ of bank loans that were applied for and granted by bankers. Credit rationing concerns a low proportion of the total population of surviving firms $(8.08 \%)$. On the other hand, it appears more difficult for the banker to discriminate bad firms. Some $80.71 \%$ of firms that failed had actually received a bank loan.

To add some insights about the robustness of our analysis, we confront, among the firms that have asked for bank loans at start, firms still alive that have obtained a bank loan against closed down firms that did not obtained a bank loan. This subsample of firms corresponds therefore to the subsample for which the ex-ante bank decision was right. The results reveal that the two groups of firms are significantly different. The information included in the logistic model allows the right classification of more than $82 \%$ of the bank decisions. If the global specification of the model was not significant, we would infer that the banker discriminates using unknown variables that are omitted from the data. Further interpretation goes along the idea that unobserved heterogeneity would be here a relatively subsidiary problem. 
Table 5. Factors affecting the survival of the firm

\begin{tabular}{|c|c|c|}
\hline Number of observations: 22760 & Modalities & $\begin{array}{c}\text { Model 2 Survival } \\
\text { Alive firms: } 14167 \text { observations }\end{array}$ \\
\hline Explanatory variable/Reference modality & Intercept & $0.395 * * *$ \\
\hline Bank loan asked/accepted & Denial of credit & $-0.676 * * *$ \\
\hline Origin/Start-up & Takeover & $0.677 * * *$ \\
\hline \multirow{7}{*}{$\begin{array}{l}\text { Branch of Activity/ } \\
\text { Trade }\end{array}$} & Agriculture and food industry & $0.198 * *$ \\
\hline & Manufacturing & $0.350 * * *$ \\
\hline & Transportation & $0.498 * * *$ \\
\hline & Construction & $0.632 * * *$ \\
\hline & Catering & $-0.326^{* * *}$ \\
\hline & Household services & $0.612 * * *$ \\
\hline & Services to firms & -0.050 \\
\hline Public financial aid/Non obtained & Obtained & $0.147 * * *$ \\
\hline \multirow{3}{*}{$\begin{array}{c}\text { Initial size of the firm/ } \\
\text { No employee }\end{array}$} & 1 employee & 0.030 \\
\hline & $2-5$ employees & -0.042 \\
\hline & +5 employees & $-0.330 * * *$ \\
\hline \multirow{7}{*}{ 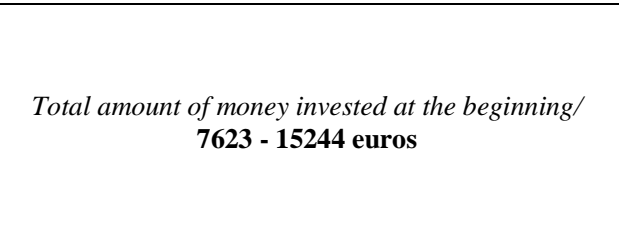 } & Less than 1525 euros & -0.042 \\
\hline & $1525-3811$ euros & 0.066 \\
\hline & $3812-7622$ euros & 0.073 \\
\hline & $15245-38112$ euros & $0.350 * * *$ \\
\hline & $38113-76225$ euros & $0.737 * *$ \\
\hline & $76226-152450$ euros & $0.910^{* * *}$ \\
\hline & +152450 euros & $1.216^{* * *}$ \\
\hline \multirow{2}{*}{$\begin{array}{l}\text { Nationality/ } \\
\text { French }\end{array}$} & European foreigner & $0.334 * * *$ \\
\hline & Non-European foreigner & -0.104 \\
\hline Gender/Woman & Man & $0.084 * *$ \\
\hline \multirow{6}{*}{$\begin{array}{l}\text { Age of the entrepreneur/ } \\
\mathbf{3 0}-\mathbf{3 5} \text { years old }\end{array}$} & -25 years old & $-0.551 * * *$ \\
\hline & $25-30$ years old & $-0.251 * * *$ \\
\hline & $35-40$ years old & $-0.087 *$ \\
\hline & $40-45$ years old & $-0.101^{*}$ \\
\hline & $45-50$ years old & $-0.179 * * *$ \\
\hline & +50 years old & $-0.124 *$ \\
\hline \multirow{7}{*}{ Previous professional status/Employee } & Craftsman & 0.062 \\
\hline & Manager & $0.177 * *$ \\
\hline & Supervisor worker & $0.416^{* * *}$ \\
\hline & Middle management position & -0.049 \\
\hline & Executive & $0.245 * * *$ \\
\hline & Worker & $0.232 * * *$ \\
\hline & Student & $-0.108^{*}$ \\
\hline \multirow{3}{*}{$\begin{array}{l}\text { Previous occupation of the entrepreneur/ } \\
\text { Labor force }\end{array}$} & Short term unemployed & $-0.271 * * *$ \\
\hline & Long term unemployed & $-0.353 * * *$ \\
\hline & Non-working & $-0.692 * * *$ \\
\hline \multirow{4}{*}{$\begin{array}{l}\text { Level of diplomal } \\
\text { Intermediate level }\end{array}$} & No diploma & $-0.308 * * *$ \\
\hline & Secondary school diploma & $0.104^{*} *$ \\
\hline & Till two years at university & $0.151 * * *$ \\
\hline & From three years and more at university & $0.673 * * *$ \\
\hline \multirow{3}{*}{$\begin{array}{l}\text { Experience in the same branch of activity/ } \\
\text { No experience }\end{array}$} & Close vocational experience & $-0.465 * * *$ \\
\hline & Different experience & $-0.867 * * *$ \\
\hline & Close experience for the partner & $-0.847 * * *$ \\
\hline \multirow{3}{*}{$\begin{array}{l}\text { Length of the experiencel } \\
\text { More than } 10 \text { years }\end{array}$} & No experience & $-0.419 * * *$ \\
\hline & 3 years experience & $-0.234 * * *$ \\
\hline & $3-10$ years experience & $-0.139 * * *$ \\
\hline \multirow{6}{*}{$\begin{array}{l}\text { Size of the firm in which the experience was acquired/ } \\
\text { Between } 4 \text { and } 9 \text { employees }\end{array}$} & Less than 3 employees & -0.003 \\
\hline & Between 10 and 49 employees & $-0.205^{* * *} *$ \\
\hline & Between 50 and 99 employees & $-0.268 * * *$ \\
\hline & Between 100 and 199 employees & -0.044 \\
\hline & Between 200 and 499 employees & -0.149 \\
\hline & More than 500 employees & $-0.336^{* * * *}$ \\
\hline Entrepreneurial milieu/Family or friends & No & $0.075 * *$ \\
\hline \multirow{4}{*}{$\begin{array}{l}\text { Main motivation to set up his firm/ } \\
\text { Taste for entrepreneurship }\end{array}$} & Start for new idea & -0.070 \\
\hline & Catch an opportunity & $0.124 * * *$ \\
\hline & Start for necessity & $-0.216^{* * *}$ \\
\hline & Example of the surrounding & $-0.185^{* *}$ \\
\hline Other current entrepreneurial involvement/No & Yes & 0.090 \\
\hline \multirow{3}{*}{$\begin{array}{c}\text { Previous setting up of new firms/ } \\
\text { No }\end{array}$} & 1 startup & -0.035 \\
\hline & 2 or 3 startups & $-0.670 * * *$ \\
\hline & +4 startups & 0.201 \\
\hline LR ratio: null hypothesis $\beta=0$ & \multirow{2}{*}{ DF: Degree of Freedom: 64} & $3617.064 * * *$ \\
\hline Percent Concordant & & $71.3 \%$ \\
\hline
\end{tabular}

Note: $*$ (respectively $* *, * * *)$ means the rejection of the null hypothesis for a $10 \%$ threshold (respectively $5 \%, 1 \%$ ). 


\subsection{Banking errors and their factors}

In this section, we contribute to identify the factors, linked to the starter, the project or the industry, that are closely associated with credit rationing and/or overlending. This is achieved through multivariate analysis of the banking errors' occurrence. The tested factors of credit rationing (Model 3) and overlending (Model 4) are reported in Table 6.

Credit rationing affects 1,143 out of 14,167 firms that were still alive three years after their founding (Table 6, Model 3). Credit rationing is more frequent among firms with a very low amount of equity at birth (less than 1,525 €) and with a relatively high number of employees (more than five). Credit rationing appears more frequent as well when entrepreneurs are not French. This could be the sign of a discrimination form but also being linked to the fact that foreign people can face some difficulty in providing collaterals inside the country of France. Additionally, foreigners may be less informed about local financing funds and less inserted into local networks. Exploiting data from the Italian Survey of Household Income and Wealth (SHIW) collected in the 1990s, Michelacci and Silva (2007) show that the share of local entrepreneurs that setup their firm in their native region is more important than the corresponding share of salaried people. The discrepancy between shares is, moreover, greater in the more developed regions. It increases according to the degree of development of the local finance (as measured by Guiso et al., 2004). According to these authors, evidence suggests that "there are so many local entrepreneurs because locals can better exploit the financial opportunities available in the region where they were born" (Michelacci and Silva, 2007, p. 615). The credit rationing is also more frequent when entrepreneurs are men; (short and long term) unemployed or without any activity before start (compared to being part of the labor force), when they have attained the Secondary school-level or are undergraduates, when their experience is less than 3 years, when starting a new firm is linked to necessity motive, or when they have prior entrepreneurial experience. Past experience in a firm counting more than 50 employees increases the probability of credit rationing as well. On the contrary, credit rationing is less probable among takeovers; in all sectors, except services to firms (non-significant; Trade being the reference modality); when public financial aid has been obtained. The probability of credit rationing is also decreasing with the amount of capital invested at start; some past professional experience, i.e. having been a craftsman or a supervising worker (compared to having been an employee), having experimented the branch in which the new firm is active before.

Out of the population of firms that did not survive three years after founding $(8,593$ firms), overlending affected 6,935 firms (Table 6, Model 4). Overlending is more frequent among takeovers; in some sectors, i.e. the agriculture and food industry, the catering and household 
services industries (Trade being the reference modality); when firms benefited from public financial aid. The probability of overlending is also increasing with the amount of capital invested at start and with the experience of having been a craftsman. Contrarily, the probability of overlending decreases with the number of employees. Overlending is also less probable when the entrepreneur is non-European; a man; was (short and long term) unemployed or without any activity before start (compared to having been part of the labor force); when the entrepreneur's motive to create is based on necessity or a new idea, and when previous professional status means having been a worker or a supervising worker. 
Table 6. Factors affecting the likelihood of bankers to make errors

\begin{tabular}{|c|c|c|c|}
\hline & \multirow{2}{*}{ Modalities } & $\begin{array}{l}\text { Model 3-Rationing } \\
\text { Credit rationing: } \\
1143 \text { observations } \\
\end{array}$ & $\begin{array}{l}\text { Model 4-Overlending } \\
\text { Overlending: } \\
6935 \text { observations } \\
\end{array}$ \\
\hline & & $\begin{array}{l}\text { Still alive firms: } \\
14167 \text { observations }\end{array}$ & $\begin{array}{l}\text { Close down firms: } \\
8593 \text { observations }\end{array}$ \\
\hline Explanatory variable/Reference modality & Intercept & $-2.010^{* * *}$ & $2.348 * * *$ \\
\hline Origin/Start-up & Takeover & $-0.693 * * *$ & $0.387 * * *$ \\
\hline \multirow{7}{*}{$\begin{array}{l}\text { Branch of Activity/ } \\
\text { Trade }\end{array}$} & Agriculture and food industry & $-1.966 * * *$ & $0.608 * * *$ \\
\hline & Manufacturing & $-0.332 * * *$ & -0.115 \\
\hline & Transportation & $-0.642 * * *$ & 0.081 \\
\hline & Construction & $-0.590 * * *$ & $-0.365 * * *$ \\
\hline & Catering & $-0.902 * * *$ & $0.418 * * *$ \\
\hline & Household services & $-1.446 * * *$ & $0.220 * *$ \\
\hline & Services to firms & 0.036 & $-0.440 * * *$ \\
\hline Public financial aid/Non obtained & Obtained & $-0.656 * * *$ & $0.740 * * *$ \\
\hline \multirow{3}{*}{$\begin{array}{c}\text { Initial size of the firm/ } \\
\text { No employee }\end{array}$} & 1 employee & -0.102 & $-0.269 * * *$ \\
\hline & $2-5$ employees & -0.051 & $-0.366^{* * *}$ \\
\hline & +5 employees & $0.522 * * *$ & $-1.349 * * *$ \\
\hline \multirow{7}{*}{$\begin{array}{c}\text { Total amount of money invested at the } \\
\text { beginning/ } \\
\mathbf{7 6 2 3}-\mathbf{1 5 2 4 4} \text { euros }\end{array}$} & Less than 1525 euros & $0.540 * * *$ & $-1.376^{* * *}$ \\
\hline & $1525-3811$ euros & 0.034 & $-0.840^{* * *}$ \\
\hline & $3812-7622$ euros & -0.135 & $-0.455^{* * *}$ \\
\hline & $15245-38112$ euros & $-0.717 * * *$ & -0.135 \\
\hline & $38113-76225$ euros & $-0.878 * * *$ & $0.434 * * *$ \\
\hline & $76226-152450$ euros & $-1.100 * * *$ & $0.870 * * *$ \\
\hline & +152450 euros & $-3.678 * * *$ & $1.267 * * *$ \\
\hline \multirow{2}{*}{$\begin{array}{l}\text { Nationality/ } \\
\text { French }\end{array}$} & European foreigner & $0.722 * * *$ & 0.244 \\
\hline & Non-European foreigner & $0.621 * * *$ & $-1.839 * * *$ \\
\hline Gender/Woman & Man & $0.217 * *$ & $-0.309 * * *$ \\
\hline \multirow{6}{*}{$\begin{array}{l}\text { Age of the entrepreneur/ } \\
\mathbf{3 0}-\mathbf{3 5} \text { years old }\end{array}$} & -25 years old & $-0.347 * *$ & $0.332 * * *$ \\
\hline & $25-30$ years old & $-0.445 * * *$ & $0.258 * * *$ \\
\hline & $35-40$ years old & $-0.333 * * *$ & -0.080 \\
\hline & $40-45$ years old & $-0.250 * *$ & $0.472 * * *$ \\
\hline & $45-50$ years old & $-0.280^{* *}$ & 0.172 \\
\hline & +50 years old & -0.020 & $0.417 * * *$ \\
\hline \multirow{7}{*}{ Previous professional status/Employee } & Craftsman & $-0.385 * *$ & $0.412 * * *$ \\
\hline & Manager & -0.012 & -0.093 \\
\hline & Supervisor worker & $-0.794 * * *$ & $-0.352 * *$ \\
\hline & Middle management position & 0.129 & -0.190 \\
\hline & Executive & 0.168 & -0.036 \\
\hline & Worker & 0.090 & $-0.262 * * *$ \\
\hline & Student & -0.081 & -0.128 \\
\hline \multirow{3}{*}{$\begin{array}{l}\text { Previous occupation of the entrepreneur/ } \\
\text { Labor force }\end{array}$} & Short term unemployed & $0.788 * * *$ & $-0.794 * * *$ \\
\hline & Long term unemployed & $1.283 * * *$ & $-0.830^{* * *}$ \\
\hline & Non-working & $0.985 * * *$ & $-0.341 * *$ \\
\hline \multirow{4}{*}{$\begin{array}{l}\text { Level of diploma/ } \\
\text { Intermediate level }\end{array}$} & No diploma & 0.039 & $0.165^{*}$ \\
\hline & Secondary school diploma & $0.178^{*}$ & -0.111 \\
\hline & Till two years at university & $0.516^{* * *}$ & 0.043 \\
\hline & $\begin{array}{l}\text { From three years and more at } \\
\text { university }\end{array}$ & 0.006 & -0.195 \\
\hline \multirow{3}{*}{$\begin{array}{l}\text { Experience in the same branch of activity/ } \\
\text { No experience }\end{array}$} & Close vocational experience & $-0.690 * * *$ & 0.031 \\
\hline & Different experience & 0.118 & -0.061 \\
\hline & Close experience for the partner & -0.024 & -0.227 \\
\hline \multirow{3}{*}{$\begin{array}{l}\text { Length of the experiencel } \\
\text { More than } 10 \text { years }\end{array}$} & No experience & $1.463 * * *$ & $0.565 * *$ \\
\hline & 3 years experience & $0.791 * * *$ & -0.130 \\
\hline & $3-10$ years experience & 0.131 & -0.058 \\
\hline \multirow{6}{*}{$\begin{array}{l}\text { Size of the firm in which the experience was } \\
\text { acquired/ } \\
\text { Between } 4 \text { and } 9 \text { employees }\end{array}$} & Less than 3 employees & -0.109 & -0.176 \\
\hline & Between 10 and 49 employees & 0.022 & $0.330 * * *$ \\
\hline & Between 50 and 99 employees & $0.622 * * *$ & -0.156 \\
\hline & Between 100 and 199 employees & $0.401 * *$ & $0.833^{* * *}$ \\
\hline & Between 200 and 499 employees & $0.402 *$ & $-0.850 * * *$ \\
\hline & More than 500 employees & $0.523 * * *$ & -0.057 \\
\hline Entrepreneurial milieu/Family or friends & No & 0.061 & $-0.248 * * *$ \\
\hline \multirow{4}{*}{$\begin{array}{l}\text { Main motivation to set up his firm/ } \\
\text { Taste for entrepreneurship }\end{array}$} & Start for new idea & $-0.298 * *$ & $-0.287 * * *$ \\
\hline & Catch an opportunity & -0.113 & 0.031 \\
\hline & Start for necessity & $0.652 * * *$ & $-0.301 * * *$ \\
\hline & Example of the surrounding & $-0.836^{* * *} *$ & -0.081 \\
\hline Other current entrepreneurial involvement/No & Yes & $0.228 *$ & $-0.257 * *$ \\
\hline & 1 startup & $0.640 * * *$ & -0.174 \\
\hline Previous setting up of new firms/ & 2 or 3 startups & $0.932 * * *$ & -0.125 \\
\hline & +4 startups & $1.357 * * *$ & 0.059 \\
\hline LR ratio: null hypothesis $\beta=0$ & DF. Deoree of Freedom 63 & $1438.065^{* * * *}$ & $1203.068 * * *$ \\
\hline Percent Concordant & DF: Degree or Freedom: 63 & $74.9 \%$ & $71.6 \%$ \\
\hline
\end{tabular}

Note: $*$ (respectively $* *, * * *)$ means the rejection of the null hypothesis for a $10 \%$ threshold (respectively $5 \%, 1 \%$ ). 
The results obtained by estimation of Models 3 and 4 reveal that some factors linked to the starter, the project or the industry, are significantly, positively or negatively, associated with bankers' errors, i.e. credit rationing and/or overlending. In the case of credit rationing, bankers tend to underestimate the viability of the project while in the case of overlending, they appear overconfident. And so, the results suggest quite interestingly that some factors provide fertile ground for bankers' misjudgments or, instead, contribute to reduce them. What could be the reasons for that? If one has in mind to connect the obtained results with the bankers' decisions, answering the question would first require that the factors tested here be confronted more closely to those entering scoring models used by bankers to assess loan applications; not only the factors but their weights as well. That being the case, and in accordance with the rationale behind the models proposed by Stiglitz and Weiss and De Meza and Webb, imperfect information substitutes can be used to guide decision-making. It can be statistical information based on (a sample of) (past) observations, without or with some expertise information being included as in Bayesian decision-making. In practice, the occurrence of particular beliefs and attitudes that bankers develop through their own, subjective, experience, interpretation and learning cannot be excluded from the decision-making process (Andersson, 2004, Trönnberg and Hemlin, 2012). Moreover, when they are shared by bankers as a group, particular beliefs and attitudes can lead to systematic over- or underweighting of some factors. The argument would represent a hypothetical explanation for some obtained results regarding, for example, nationality (being a [non-European] foreigner), previous occupation of the credit applicant (being unemployed) or the origin of the project (start-up versus takeover).

The results show that most significant factors enter into a consistent relation across models: when they are positively (negatively) associated with credit rationing, they are negatively (positively) associated with overlending. Few (i.e., 2) of the factors are positively associated with both credit rationing and overlending. Interestingly, three of them are linked with a reduction of the two types of errors. 
Table 7. Modalities combining the two types of errors: credit rationing and overlending

\begin{tabular}{|c|c|c|c|c|}
\hline \multicolumn{5}{|c|}{ Credit rationing } \\
\hline \multirow{4}{*}{ 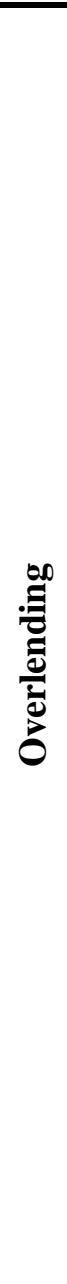 } & Sign & - & Ns & + \\
\hline & - & $\begin{array}{l}\text { Construction } \\
\text { Supervisor worker } \\
\text { Start for new idea }\end{array}$ & $\begin{array}{c}\text { Services to firms } \\
1 \text { employee } \\
2-5 \text { employees } \\
1525-3811 \text { euros } \\
3812-7622 \text { euros } \\
\text { Worker } \\
\text { No entrepreneurial milieu }\end{array}$ & $\begin{array}{c}5 \text { employees } \\
\text { Less than } 1525 \text { euros } \\
\text { Non-European foreigner } \\
\text { Man } \\
\text { Short term unemployed } \\
\text { Long term unemployed } \\
\text { Non-working } \\
\text { Between } 200 \text { and } 499 \text { employees } \\
\text { Start for necessity } \\
\text { Having other current entrepreneurial } \\
\text { involvement }\end{array}$ \\
\hline & Ns & $\begin{array}{c}\text { Manufacturing } \\
\text { Transportation } \\
15245-38112 \text { euros } \\
35-40 \text { years old } \\
45-50 \text { years old } \\
\text { Close vocational experience } \\
\text { Example of the surrounding }\end{array}$ & $\begin{array}{c}\text { Manager } \\
\text { Middle management position } \\
\text { Executive } \\
\text { Student } \\
\text { From three years and more at university } \\
\text { Different experience } \\
\text { Close experience for the partner } \\
3-10 \text { years experience } \\
\text { Less than } 3 \text { employees } \\
\text { Catch an opportunity }\end{array}$ & $\begin{array}{c}\text { European foreigner } \\
\text { Secondary school diploma } \\
\text { Till two years at university } \\
3 \text { years experience } \\
\text { Between } 50 \text { and } 99 \text { employees } \\
\text { More than } 500 \text { employees } \\
1 \text { startup } \\
2 \text { or } 3 \text { startups } \\
+4 \text { startups }\end{array}$ \\
\hline & + & $\begin{array}{c}\text { Takeover } \\
\text { Agriculture and food industry } \\
\text { Catering } \\
\text { Household services } \\
\text { Public financial aid } \\
38113-76225 \text { euros } \\
76226-152450 \text { euros } \\
+152450 \text { euros } \\
-25 \text { years old } \\
25-30 \text { years old } \\
40-45 \text { years old } \\
\text { Craftsman }\end{array}$ & $\begin{array}{c}+50 \text { years old } \\
\text { No diploma } \\
\text { Between } 10 \text { and } 49 \text { employees }\end{array}$ & $\begin{array}{c}\text { No experience } \\
\text { Between } 100 \text { and } 199 \text { employees }\end{array}$ \\
\hline
\end{tabular}

From Table 7, we can see that receiving public financial aid, having a sizeable project, being a takeover, in sectors like catering, agriculture and food industry or household services, go along with a reduction of credit rationing but also an increase of overlending. So, in that case, if the corresponding information would allow a better discrimination of ex-ante good projects, it would also induce overconfidence about the viability of some projects that will finally fail. At the opposite, being long or even short term unemployed, being out of work, being a $\operatorname{man}^{9}$ and from non-European origin would go with an increase in credit rationing and a decrease in overlending. In that case, the corresponding information would induce an excess of severity about actually viable projects but also a better discrimination of some weak projects that are doomed to fail and that will not be financed.

\footnotetext{
${ }^{9}$ One might expect women being more credit rationed but this is not to mention that women might be relatively more represented among self-constrained.
} 
Additionally, we may note that public financial aid makes the frequency of credit rationing decrease, but appears to lead to an increase in overlending. Along with public financial aid, banks grant more credit, but some might be granted to future bad firms. If the goal of the policy makers is to decrease credit rationing, the allowance of public financial aid meets it but this is not mentioning some concern for the efficiency of public transfers. Our results suggest as well that there might exist other channels to enhance the global efficiency of the credit market. Indeed, we identify some variables that make credit rationing decrease without simultaneously increasing overlending. Having experience in the same or in a close branch of activity than the new firm, for example, goes along a decrease in credit rationing without entering into a significant relation with overlending. We also observe that some rare factors seem to globally improve the efficiency of market credit by decreasing both credit rationing and overlending. It is the case when a new idea was the underlying motive for the new firm. A hypothetical explanation could be that, everything else being equal, dealing with a new idea means for the banker going outside the box and collecting more information in order to assess the original project. By collecting more information, bankers would improve their decision making.

\section{6- Conclusion}

Examining the consequence of asymmetric information on the credit market, credit rationing theory à la Stiglitz and Weiss (1981) has been vigorously challenged by De Meza and Webb (1987, 2000) suggesting that firms can rather benefit from an excess of credit, i.e. overlending. Due to asymmetric information, banks cannot perfectly discriminate between good and bad firms, and credit rationing and overlending may be regarded as wrong decisions or errors made by bankers arising from this imperfect discrimination. Moreover, they are in a way the two sides of the same issue. Everything else being equal, particularly in terms of information, a reduction in credit rationing goes along with an increase in overlending, and vice versa. From an empirical perspective, the issue leads to the question of their relative commonness or rarity, and whether we can identify factors that might lead to one or the other. And it is precisely from this respect that this empirical article ambitioned to contribute.

Measuring credit rationing and overlending requires to have access to a rich panel dataset, with information all together on the demand of credit, the credit decision by the bank and the fate of the borrower (for new firms: Did they survive or not?). By exploiting the French SINE panel dataset about new firms, we were able to give an estimate of the situation that prevailed in France during the mid-1990s. Our results show that credit rationing was not highly spread among French new firms. The story described by De Meza and Webb (1987) appears to be a much more realistic 
model. This may appear quite appealing, as it suggests that banks opt for the strategy of minimizing credit demand rejection even if it is at the cost of accepting a larger proportion of bad risks. But, when we think about it, it is not such a surprise. For the banks, as we emphasized it before, overlending does not necessarily mean total loss of their grant: in case of firm failure, banks might be secured creditors and among the first to be paid back; not to mention, collaterals.

By applying multivariate analysis, we were also able to identify factors, about the starter, the project or the industry, that are closely connected to credit rationing and/or overlending. Most factors enter into a consistent relation: when they are positively (negatively) associated with credit rationing, they are negatively (positively) associated with overlending. We shall not be exhaustive but some factors, concerning the starter and the project, retain our attention. About the former, some traits, i.e. being a non-European foreigner and being jobless, appear detrimental as they increase credit rationing. Regarding the latter, taking over a firm and receiving public financial aid coincide repeatedly with overlending. The likelihood of overlending is also increasing with the amount of capital invested at start. Remarkably enough, the cited factors going along with credit rationing refer to the starter, whereas those factors that concur with overlending refer to the project.

By collecting more information, bankers would improve their decision making and the global efficiency of the credit market. But collecting and treating information represent a cost that the bankers will only accept if it is (over-)compensated by the expected benefit. Information imperfection will certainly not be reduced to zero without involving an infinite cost (or because it is impossible). That being said, intermediary situations give room for public intervention, through public guarantee, subsidy and more sophisticated measures (Cowling, 2012; Eslava and Freixas, 2016). Along with additional studies that it calls for - studies exploring more recent and more comprehensive data; for different contexts -, we believe that this study might contribute in detecting in a more systematic way the sources of credit market imperfection. Such an achievement would help in defining more efficient and targeted policy measures. 


\section{References}

Abdesselam, R., Bonnet, J. \& Le Pape, N. (2004), “An Explanation of the Life Span of New French Firms", Small Business Economics, 23, 237-254.

Abdesselam, R., Bonnet, J. \& Renou-Maissant, P. (2014), "Typology of the French regional development: revealing the refugee versus Schumpeter effects in new-firm startups", Applied Economics, 46, 28, 3437-3451.

Allen, F., Santomero, A. (1998), “The Theory of Financial Intermediation”, Journal of Banking and Finance, 21, 1461-1485.

Andersson, P. (2004), "Does experience matter in lending? A process-tracing study on experienced loan officers' and novices' decision behavior", Journal of Economic Psychology, 25, 4, 471-492.

Aubier, M., Cherbonnier, F. (2007), "L'accès des entreprises au crédit bancaire”, Economie et Prévision, 1777, 121-128.

Audretsch, D., Mahmood, T. (1995), "New Firm Survival: New Results Using a Hazard Function", Review of Economics and Statistics, 77, 97-103.

Banque de France (undated), Exercice 1994, Rapport adressé à Monsieur le Président de la République et au Parlement par M. Jean-Claude Trichet, Gouverneur.

Bastié, F., Cieply, S. \& Cussy, P. (2013), “The entrepreneur's mode of entry: the effect of social and financial capital”, Small Business Economics, 40, 865-877.

Bates, T. (1990), "Entrepreneur human capital inputs and small business longevity", Review of economics and statistics, 72, 551-559.

Bates, T. (2005), "Analysis of young, small firms that have closed: delineating successful from unsuccessful closures", Journal of Business Venturing, 20, 3, 343-358.

Becchetti, L., Castelli, A. \& Hasan, I. (2010), "Investment cash flow sensitivities, credit rationing and financing constraints in small and medium-sized firms", Small Business Economics, 35, 467-497.

Bel, G. (2009), "L'entrepreneuriat au féminin, Communication du Conseil économique, social et environnemental", 22 septembre.

Benston, G., Smith, C. (1976), "A Transaction Cost Approach To the Theory of Financial Intermediation", Journal of Finance, 2, 215-231.

Berger, A., Udell, G. (1998), “The Economics of Small Business Finance: The Roles of Private Equity and Debt Markets In the Financial Growth Cycle", Journal of Banking and Finance, 22, 613-673.

Bhattacharjee, A., Bonnet, J., Le Pape, N., \& Renault, R. (2008), "Entrepreneurial motives and performance: Why might better educated entrepreneurs be less successful?", Working Paper du THEMA.

Bhattacharya, S., Boot, A., \& Thakor, A. (2004), Credit, Intermediation and the Macroeconomy, Oxford: OUP.

Bhattacharya, S., Thakor, A. (1993) "Contemporary Banking Theory", Journal of Financial Intermediation, 3, 2-50.

Blumberg, B. \& Letterie, W. (2008), "Business Starters and Credit Rationing”, Small Business Economics, 30, 187-200.

Cagetti, M., De Nardi, M. (2006), "Entrepreneurship, Frictions, and Wealth", Journal of Political Economy, 114, 5, 835-870.

Cieply, S., Paranque, B. (1998), "Le rationnement des petites entreprises sur le marché du crédit: mythe ou réalité ?", Revue Banque \& Marchés, 33, mars-avril, 5-17.

Cowling, M. (2012), “Credit rationing, equity gaps', and policy solutions for financing entrepreneurial business in Europe: Theory, tests, evidence and the design and effectiveness of policy instruments", Report to the European Commission, Directorate-General Regional Policy.

Cressy, R. (1996), “Are Business Start-ups Debt-Rationed?” Economic Journal, 438, 1253-1270.

De Meza, D.E. (2002), “Overlending?”, The Economic Journal, 112, 17-30.

De Meza, D.E., Webb, D.C. (1987), "Too Much Investment: a Problem of Asymmetric Information”, Quarterly Journal of Economics, 102, 281-292. 
De Meza, D.E., Webb, D.C. (2000), “Does Credit Rationing Imply Insufficient Lending?”, Journal of Public Economics, 78, 215-234.

De Meza, D.E., Webb, D.C. (2006), “Credit Rationing: Something's Gotta Give”, Economica, 73, 563-578.

Désiage, L., Duhautois, R. \& Redor, D. (2011), "A study of young firm dynamics: the transition from zero to one or more employees", Paper presented at the 8th ENEF Meeting, Strasbourg, 7-8 September.

Diamond, D. (1984), "Financial Intermediation and Delegated Monitoring “, Journal of Economic Studies, LI, 393-414.

Diamond, D., Rajan, R. (2001), "Liquidity Risk, Creation and Financial Fragility: A Theory Of Banking", Journal of Political Economy, 2, 287-327.

Eslava, M., Freixas, X. (2016), "Public development banks and credit market imperfections", CEPR Discussion Paper 11160.

Evans, D., Jovanovic B. (1989), “An Estimated Model of Entrepreneurial Choice under Liquidity Constraints", Journal of Political Economy, 97, 4, 808-827.

Evans, D., Leighton, L. (1989), "Some empirical aspects of entrepreneurship", The American Economic Review, 79: 519-535

Fairlie, R., Krashinsky, H. (2012), "Liquidity Constraints, Household Wealth and, Entrepreneurship Revisited", Review of Income and Wealth, 58, 2, 279-306.

Fairlie, R., Robb, A. (2006), "Families, human capital, and small business: Evidence from the Characteristics of Business Owners Survey". In M. Van Praag, ed., Entrepreneurship and Human Capital, Amsterdam Center for Entrepreneurship, Faculty of Economics and Business, University of Amsterdam, The Netherlands, July, 5-11.

Fama, E.F. (1985), "What's Different about Banks?”, Journal of Monetary Economics, 1, 29-39.

Fazzari, S., Hubbard R. \& Petersen B. (1988), "Financing Constraints and Corporate Investment", Brookings Papers on Economic Activity, 19, 1, 141-206.

Frankish, J.S., Roberts, R.G., Coad, A., Spears, T.C. \& Storey D.J. (2013), "Do entrepreneurs really learn? Or do they just tell us that they do?", Industrial and Corporate Change, 22, 1, 73-106.

Freixas, X., Rochet J. (1999), Microeconomics of Banking, Cambridge, Mass.: MIT Press.

Geroski, P.A., Mata, J. \& Portugal, P. (2002), "Founding Conditions and the Survival of New Firms", Strategic Management Journal, 31, 510-529.

Goodhart, C.A.E. (1989), Money, Information and Uncertainty, Basingstoke: Macmillan.

Guiso, L. (1998), "High Tech firms and credit rationing", Journal of Economic Behavior \& Organization, $35,39-59$.

Guiso, L., Sapienza, P. \& Zingales, L. (2004), "Does local financial development matter ?”, Quarterly Journal of Economics, 119, 3, 929-969.

Kaplan, S., Zingales, L. (1997), "Do Investment-Cash Flow Sensitivities Provide Useful Measures of Financing Constraints?", Quarterly Journal of Economics, 112, 1, 169-215.

Keynes, J.M. (1930), A Treatise on Money. In The Collected Writings of John Maynard Keynes, Volume VI, The Applied Theory of Money, New York: Cambridge University Press, 1971.

Kon, Y., Storey, D.J. (2003), “A Theory of Discouraged Borrowers", Small Business Economics, 21, 3749.

Kremp, E., Sevestre, P. (2013). "Did the crisis induce credit rationing for French SMEs?", Journal of Banking \& Finance, 37, 10, 3757-3772.

Levenson, A., Willard, K. (2000), "Do firms get the financing they want? Measuring credit rationing experienced by small businesses in the U.S.", Small Business Economics, 14, 83-94.

Mankiw, N., Romer, D., eds (1991a), New Keynesian Economics - Vol. 1: Imperfect Competition and Sticky Prices, Cambridge, Mass.: MIT Press.

Mankiw, N., Romer, D., eds (1991b), New Keynesian Economics - Vol. 2: Coordination Failures and Real Rigidities, Cambridge, Mass.: MIT Press.

Michelacci, C., Silva O. (2007), "Why so many local entrepreneurs?", Review of Economics and Statistics, $89,4,615-633$. 
Nelson, T., Vosmek, S. (2014), "Investing in Women High Growth Entrepreneurs, Their Teams and Their Ventures", Astia White Paper (available on March 2016 from: http://astia.org/wpcontent/uploads/2014/10/Astia_White_Paper.pdf).

Nykvist, J. (2008), "Entrepreneurship and Liquidity Constraints: Evidence from Sweden”, Scandinavian Journal of Economics, 2008, 110, 1, 23-43.

Parker, S.C., van Praag, C.M. (2006), "Schooling, Capital Constraints and Entrepreneurial Performance: the Endogenous Triangle", Journal of Business and Economic Statistics, 24, 4, 416-431.

Piga, C., Atzeni, G. (2007), "R\&D Investment, Credit Rationing and Sample Selection", Bulletin of Economic Research, 59, 149-178.

Ruhle, I. (1997), "Why Banks? Microeconomic Foundation of Financial Intermediaries”, Development and Finance, 3, 10-99.

Smith, A. (1776), An Inquiry into the Nature and Causes of the Wealth of Nations. Edited by Edwin Cannan, Chicago: University of Chicago Press, 1976.

Stiglitz, J.E., Weiss A. (1981), "Credit Rationing In Markets With Imperfect Information", The American Economic Review, 3, 393-410.

Trönnberg, C.C., Hemlin S. (2012), "Banker's lending decision making: a psychological approach", Managerial Finance, 38, 11, 1032-1047.

Turgot, A. R. J. (1766), "Réflexions sur la formation et la distribution des richesses". In A. R. J. Turgot, Écrits économiques, Paris: Calmann-Lévy, 1970 (préface de B. Cazes).

Turgot, A. R. J. (1770), "Mémoire sur le prêt d'argent", In A. R. J. Turgot, Écrits économiques, Paris: Calmann-Lévy, 1970 (préface de B. Cazes). 